New Delhi

THE leak of toxic gas from the Union Carbide pesticide plant in the central Indian town of Bhopal on 3 December has left at least 2,500 people dead and killed hundreds of cattle. The death toll is likely to increase, with thousands still in hospital three days after the disaster, which affected 200,000 people living within a $7-\mathrm{km}$ radius of the plant. The cause of the leak is being investigated by chemicals experts with the help of a team flown in by the US multinational company. Meanwhile, the state government of Madhya Pradesh has arrested six workers, including the plant manager, ordered indefinite closure of the plant and started a judicial inquiry. The Central Bureau of Investigations is looking into the possibility of sabotage. It seems likely that Union Carbide India Limited

\section{Ways of death}

\section{Washington}

RELATIVELy little is known of the toxicological effects of methyl isocyanate, which is produced by reacting methylamine and phosgene and reacted with $\alpha$-naphthol to produce the pesticide Sevin. Its strong primary irritant properties probably accounted for the majority of deaths: conversion to cyanide is not thought to occur at a significant rate in vivo. The US Occupational Safety and Health Administration limits exposure of workers to 0.02 parts per million over an 8-hour period. Tests on rats and on human volunteers indicate that the chemical's most immediate effects are upon the respiratory tract and the cornea; in rats, the cause of death was a massive build-up of fluid in the lungs. In humans, exposure to 2 parts per million caused nose and throat irritation, 21 parts per million a suffocating effect and severe irritation of the respiratory tract and eyes.

The cause of death after acute exposure would probably be either bronchospasm or what amounts to drowning in released body fluids. Failing this, death could result from the secondary effects of loss of blood oxygen and acidosis, or from congestive heart failure. According to Dr Trent Lewis of the National Institute of Occupational Safety and Health, survivors will probably suffer increased incidence of pulmonary fibrosis, emphysema and chronic bronchitis. The respiratory tract may become hyperreactive to a variety of irritants, and changes in lung architecture may increase susceptibility to infectious pneumonia. Necrotic lesions of the cornea may lead to permanent blindness or impaired vision.

Tim Beardsley
(UCIL), the wholly-owned US subsidiary, will be faced with large claims for damages.

The killer gas was methyl isocyanate (MIC), used in the plant at Bhopal as an intermediary in the manufacture of some pesticides, including Sevin, which is widely used. According to a UCIL spokesman, the leak occurred in one of three underground tanks storing MIC, which is liquid up to $38^{\circ} \mathrm{C}$ and extremely volatile. He said the vent caustic soda scrubbers provided for neutralizing accidental releases failed to cope with an excessive pressure build-up. The tank held 45 tons at the time of the leak. It is not known how much gas escaped from the plant which, flouting existing safety guidelines, is just $1 \mathrm{~km}$ from the railway station and $5 \mathrm{~km}$ from the centre of town. UCIL said that the leak was plugged 45 minutes after it was discovered, but by that time much of the town of Bhopal had been virtually turned into a gas chamber, and was a vivid demonstration of what chemical warfare would be like.

The UCIL plant, commissioned in 1977, employs 800 workers. Ironically, the Indian government only last year extended the plant's licence for seven years after a promise from UCIL that it would secure from its parent US company the technology to handle "emergency situations like toxic gas release, sometimes accompanied with fire, endangering the safety of the community". There had been two earlier minor incidents in the Bhopal plant, one in 1981 when a leak from at phosgene storage tank killed several workers; in the latest incident, oddly enough, only one worker was injured.

In the nightmarish aftermath of Bhopal, the Indian incident is bound to become a factor in the forthcoming general election. The opposition is critical of India's policy of importing hazardous technology and pesticide licensing. The recent collaboration with Monsanto Corporation of the United States for manufacture of the herbicide butochlor, which is banned in the United States, is under attack. But pesticides made using indigenous technology in India are produced under lower safety conditions than those that existed at Bhopal, according to a spokesman for the Ministry of Chemicals. Six companies in India have been licensed to make MIC and several small pesticide manufacturers are transporting phosgene in bottles. Following the Bhopal tragedy, safety has been tightened at the state-owned Indian Petrochemicals Limited in Baroda which produces hydrocyanic acid, which is far more deadly than MIC.

\title{
UK government review
}

\section{More bad news for science}

BRITISH government expenditure in basic science is due to fall by three per cent (at constant prices) over the next two years, according to the second Annual Review of Government-Funded Research and Development (HMSO, f7.50) published on Tuesday. Prepared by the department of the Chief Scientific Adviser at the Cabinet Office, Dr Robin Nicholson, this is a second and more accurate shot at determining the trends and distribution of government science spending.

The figures were prepared too late to include the recent goings-on at the Department of Education and Science (see p.582), but they do add some grist to the argument that science in Britain is threatened. Compared with 1983-84 expenditure, and in real terms, the Cabinet Office expected the Economic and Social Research Council budget to have have fallen to 84 per cent of its original value by 1986-87; Agricultural and Food to 91 per cent; Medical to 94 per cent; Natural Environment to 98 per cent; and Science and Engineering to have risen to a princely 101 per cent.

In civil applied research ("expenditure to improve technology") things look only slightly better. The total government expenditure in this area will be $£ 807$ million in 1986-87, the Cabinet Office estimates, some 9 per cent greater in real terms than in
1983-84. But this represents a decrease from the current year (1984-85), which rides at 15 per cent above last year. The biggest projected declines to 1986-87 compared with the present year come in the Department of Energy (down 7 per cent), the Department of Environment (down 9 per cent) and significantly (as it spends half the government budget in this area) the Department of Trade and Industry (down 8 per cent).

Defence research and development, however, will be maintained at constant prices to 1986-87, although even these large sums (at $£ 7,077$ million in 1984-85 some 50.3 per cent of all governmentfunded research and development) are falling as a fraction of defence procurement.

The Cabinet Office also takes a special sectoral look in its report at British spending on marine science, in an attempt to identify "gaps and overlaps" in spending; but here it prepares the ground, unfortunately, for more cuts. "There seems cause for considering" write the authors "whether the present provision of facilities [15 towing tanks, 7 cavitation tunnels, etc.] is excessive for a shipbuilding industry which declined 30 per cent between 1975 and 1981"'. Decline, it seems, begets decline.

Robert Walgate 